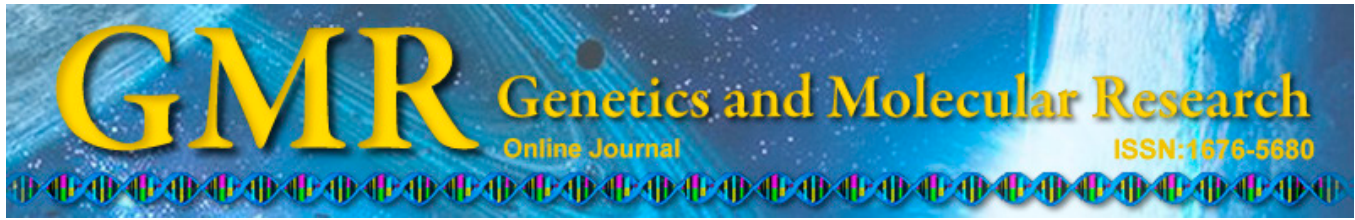

\title{
Association between FTO, MC4R, SLC30A8, and KCNQ1 gene variants and type 2 diabetes in Saudi population
}

\author{
M.D. Bazzi ${ }^{1}$, F.A. Nasr ${ }^{1}$, M.S. Alanazi ${ }^{1}$, A. Alamri ${ }^{1}$, A.A. Turjoman ${ }^{2}$, \\ A.S. Moustafa ${ }^{2}$, A.A. Alfadda ${ }^{3}$, A.A.K. Pathan ${ }^{1}$ and N.R. Parine ${ }^{1}$ \\ ${ }^{1}$ Genome Research Chair, Department of Biochemistry, College of Science, \\ King Saud University, Riyadh, Saudi Arabia \\ ${ }^{2}$ Department of Pathology, King Saud University, Riyadh, Saudi Arabia \\ ${ }^{3}$ Obesity Research Center, Department of Medicine, King Saud University, \\ Riyadh, Saudi Arabia
}

Corresponding author: N.R. Parine

E-mail: reddyparine@gmail.com

Genet. Mol. Res. 13 (4): 10194-10203 (2014)

Received January 6, 2014

Accepted July 17, 2014

Published December 4, 2014

DOI http://dx.doi.org/10.4238/2014.December.4.14

\begin{abstract}
Recent genome wide association studies identified many loci in several genes that have been consistently associated with type 2 diabetes mellitus in various ethnic populations. Among the genes that were most strongly associated with diabetes were fat mass- and obesity-associated, melanocortin 4 receptor, solute carrier family 30 member 8 (SLC30A8), and a member of the potassium voltagegated channels. In the present study, we examined the association between variants in fat mass- and obesity-associated [rs9939609 $(\mathrm{A} / \mathrm{T})]$, melanocortin 4 receptor $[\mathrm{rs} 17782313(\mathrm{C} / \mathrm{T})$, and rs12970134 $(\mathrm{A} / \mathrm{G})]$, SLC30A8 [rs13266634 (C/T)], and a member of the potassium voltage-gated channels [rs2237892(C/T)] genes in diabetes patients from Saudi Arabia. Genotypes were determined using the TaqMan single-nucleotide polymorphism genotype analysis technique. Minor allele frequency of the 4 variants tested was comparable between type
\end{abstract}


2 diabetes cases and controls. We observed an association between allele variants of SLC30A8 [rs13266634 (C/T)] and type 2-diabetes $(\mathrm{P}=0.04)$. The other single-nucleotide polymorphisms examined in this study showed moderate or no correlation with diabetes in Saudis. Our data indicate that the SLC30A8 polymorphisms are associated with type 2 diabetes in the Saudi population. There is no evidence supporting an association between variants in the fat mass- and obesity-associated and melanocortin 4 receptor, and a member of the potassium voltagegated channels genes and type 2 diabetes in the Saudi population.

Key words: Ethnicity; Fat mass- and obesity-associated; Polymorphisms; Solute carrier family 30 member 8 ; Type 2 diabetes mellitus

\section{INTRODUCTION}

Diabetes mellitus is one of the most common health problems worldwide. Type 2 diabetes (T2DM) affects more than 200 million individuals, and its prevalence is constantly increasing in most countries, including Saudi Arabia. Although the precise mechanisms underlying the development and progression of T2DM have not been fully elucidated, a combination of multiple genetic and environmental factors is considered to contribute to the pathogenesis of the disease (Wild et al., 2004; Elhadd et al., 2007; Unoki et al., 2008). It is generally accepted that T2DM is a multi-factorial disease, in which disease development is influenced by many risk factors (van Tilburg et al., 2001; Lee, 2009; Staiger et al., 2009).

Recent developments in single-nucleotide polymorphism (SNP) typing technology and the collation of information regarding linkage disequilibrium in the human genome have facilitated genome-wide association studies for investigating genes associated with disease susceptibility across the entire human genome (Unoki et al., 2008). In recently years, genomewide association studies have identified various susceptibility genetic loci associated with T2DM in several ethnic populations (Hinney et al., 2010; Ridderstråle and Groop, 2009; McCarthy, 2010). Among the implicated genes include fat mass and obesity associated (FTO) (Dina et al., 2007; Frayling et al., 2007), melanocortin 4 receptor (MC4R) (Chambers et al., 2008; Loos et al., 2008), solute carrier family 30 member 8 (SLC30A8) (Scott et al., 2007; Sladek et al., 2007; Zeggini et al., 2007), and potassium voltage-gated channel, KQT-like subfamily, member 1 (KCNQ1) (Unoki et al., 2008; Yasuda et al., 2008). A large number of common genetic variants were found to be associated with obesity phenotypes in western populations (Taylor et al., 2011). Variants in the FTO, MC4R, SLC30A8, and KCNQ1 genes have shown the strongest associations with diabetes and obesity in different populations.

Because potential associations between T2DM and particular SNPs are often population-dependent, the objectives of this study were to examine polymorphisms of these genes in a Saudi population and to assess their contributions to the development of T2DM in Saudis.

\section{MATERIAL AND METHODS}

\section{Study population}


A total of 185 blood samples were obtained from King Khalid University Hospital, including 90 patients with T2DM and 95 healthy controls. All controls were age-matched and recruited from physical examinations after diagnostic exclusion of diabetes and diabetesrelated diseases. All patients with T2DM and control subjects were examined in the morning after an overnight fast for at least $8 \mathrm{~h}$, with measurements of height, weight, and blood pressure. Blood samples were collected for biochemical measurements of fasting plasma glucose for all participants, and 2-h plasma glucose during a $75 \mathrm{~g}$ oral glucose tolerance test for the controls. Plasma glucose concentrations were measured using the glucose oxidase-peroxidase method. Controls were age- and race-matched to cases and recruited from the clinical population receiving routine check-up at King Khalid University Hospital. Subjects in the control group were all healthy individuals. None had been diagnosed with T2DM or had first-degree relatives diagnosed with T2DM. Diagnosis was based upon World Health Organization criteria (fasting plasma glucose $>7.0 \mathrm{mM}$, and/or 2-h OGTT $\geq 11.1$ ). Written informed consent was obtained from all participants, and approval was received from the King Khalid University Hospital ethics review committee. All study participants completed a self-administered baseline questionnaire, which included information on demographics, reproductive history, medical conditions, and family history of cancer.

\section{DNA extraction}

Approximately 3-mL blood samples were collected in sterile tubes containing ethylenediaminetetraacetic acid from all subjects enrolled in the study. Genomic DNA was isolated from blood samples using the QIAmp kit (QIAmp DNA blood Mini Kit, Qiagen, Hilden, Germany) following the manufacturer instructions. After extraction and purification, the DNA was quantified using a NanoDrop 8000 (NanoDrop, Wilmington, DE, USA) to determine the concentration. Purity was examined using standard $\mathrm{A}_{260} / \mathrm{A}_{280}$ and $\mathrm{A}_{260} / \mathrm{A}_{230}$ ratios (NanoDrop 8000) (Sambrook et al., 1989).

\section{Genotyping}

Five SNPs from FTO [rs9939609 (A/T)], MC4R [rs17782313 (C/T) and rs12970134 (A/G)], SLC30A8 [rs13266634 (C/T)], and KCNQ1 [rs2237892(C/T)] genes were genotyped using the TaqMan allelic discrimination assay (Livak, 1999). For each sample, 20 ng DNA per reaction was used with 5.6 $\mu \mathrm{L} 2 \mathrm{X}$ Universal Master Mix and $200 \mathrm{nM}$ primers (Applied Biosystems, Foster City, CA, USA). All genotypes were determined by endpoint reading on an ABI 7500 (Applied Biosystems). Primers and probe mix were purchased directly through the assays-on-demand service of Applied Biosystems. Five percent of the samples were randomly selected and subjected to repeat analysis as a quality control measure for verification of the genotyping procedures.

\section{Statistical analysis}

Genotype and allelic frequencies were computed and checked for deviation from Hardy-Weinberg equilibrium (http://ihg.gsf.de/cgi-bin/hw/hwa1.pl). Case-control and other genetic comparisons were performed using the chi-square test and allelic odds ratios (OR), and $95 \%$ confidence intervals (CI) were calculated by Fisher's exact test (2-tailed). Statistical 
analysis was conducted using the SPSS 16.0 for Windows (SPSS, Inc., Chicago, IL, USA). We considered a P value of $<0.05$ to be statistically significant. Chi square $\left(\chi^{2}\right)$ test was used to compare the observed genotype distributions of the FTO [rs9939609 (A/T)], MC4R [rs17782313 (C/T) and rs12970134 (A/G)], SLC30A8 [rs13266634 (C/T)], and KCNQ1 [rs2237892(C/T)] gene polymorphisms with their expected values. Allele and genotype frequencies of polymorphisms in the central region population of Saudi Arabia (CRS) were compared with some of the populations in the HapMap database (www.hapmap.org), for example, Utah residents with Northern and Western European ancestry from the CEPH collection (CEU), Han Chinese in Beijing, China (HCB), Yoruba in Ibadan, Nigeria (YRI), Maasai in Kinyawa, Kenya (MKK), Guajarati Indians in Huston (GIH) and Japanese in Tokyo, Japan (JPT), and some other populations selected from literature. Pairwise Chi square $\left(\chi^{2}\right)$ tests were performed between CRS and other populations using the allele frequencies in a $2 \times 2$ contingency table to determine whether the CRS showed significant differences compared to other populations.

\section{RESULTS}

A total of 90 T2DM cases and 95 healthy controls were included in this study. Clinical and biochemical characteristics of T2DM cases and healthy controls are shown in Table 1. All groups were of Saudi ancestry and representative of an Arab population. The allele and genotype frequencies of FTO [rs9939609 (A/T)], MC4R [rs17782313 (C/T) and rs12970134 (A/G)], SLC30A8 [rs13266634 (C/T)], and KCNQ1 [rs2237892 (C/T)] gene polymorphisms in the CRS population are shown in Table 1.

\begin{tabular}{lcc}
\multicolumn{2}{c}{ Table 1. Clinical data of the genotyped study subjects. } \\
\hline & Control & Diabetic \\
\hline N & 95 & 90 \\
Gender $(\mathrm{M} / \mathrm{F})$ & $50 / 45$ & $45 / 45$ \\
Age & $40.6 \pm 4.6$ & $50.7 \pm 11.7$ \\
$\mathrm{BMI}\left(\mathrm{kg} / \mathrm{m}^{2}\right)$ & $22.4 \pm 1.5$ & $25.2 \pm 2.0$ \\
FBS $(\mathrm{mM})$ & $5.1 \pm 0.11$ & $8.2 \pm 0.52$ \\
$2 \mathrm{HrPP}(\mathrm{mM})$ & $5.3 \pm 4.79$ & $13.0 \pm 5.4$ \\
HbAlc $(\%)$ & - & $8.0 \pm 1.7$
\end{tabular}

Data are reported as means $\pm \mathrm{SD}$. BMI = body mass index; FBS = fasting blood sugar; $2 \mathrm{hr}$ PP $=2 \mathrm{~h}$ post-prandial; $\mathrm{HbA1c}=$ glycated hemoglobin.

Except for rs13266634 (cases), all other genotypic distributions were consistent with those expected in the Hardy-Weinberg model (Table 2). The homozygous ancestral allele was used as a reference to determine the odds of acquiring diabetes in relation to the other 2 genotypes. The genotype distribution of the SNPs analyzed along with their corresponding ORs and significance values are shown in Table 2.

The genotype and allele frequencies of T2DM susceptibility gene SNPs in T2DM patients and control subjects are shown in Tables 2 and 3. Among the 5 SNPs, rs 13266634 $(\mathrm{C} / \mathrm{T})$ in SLC30A8 was significantly associated with T2DM patients in Saudi population (Table 3). The frequencies of the rs $13266634(\mathrm{C}>\mathrm{T})$ genotypes in T2DM cases were $62(0.697)$, $21(0.236)$, and $6(0.067)$ respectively, whereas as in healthy controls the frequencies were 69 (0.719), 26 (0.271), and 1 (0.01) respectively. In SNP rs13266634, the heterozygous allele (CT) and variant allele (TT) showed a significantly higher risk in diabetic patients when 
compared with controls (Table 3$)\left(\mathrm{OR}=7.429, \chi^{2}=4.1, \mathrm{P}=0.04\right.$ and $\mathrm{OR}=6.677, \chi^{2}=3.92$, $\mathrm{P}=0.04$ ) (Table 3). A significant risk in a higher proportion of patients with $\mathrm{C} / \mathrm{T}+\mathrm{T} / \mathrm{T}$ was observed in $\mathrm{T} 2 \mathrm{DM}$ cases when compared to healthy individuals $\left(\mathrm{OR}=6.867, \chi^{2}=4.12, \mathrm{P}=\right.$ 0.04) (Table 3).

\begin{tabular}{|c|c|c|c|c|c|}
\hline Gene/SNP & Variant & Cases & HWE P value & Controls & HWE P value \\
\hline \multirow[t]{3}{*}{ FTO/rs9939609 } & AA & $22(0.272)$ & \multirow[t]{3}{*}{0.893889} & $31(0.326)$ & \multirow[t]{3}{*}{0.202775} \\
\hline & AT & $41(0.506)$ & & $41(0.432)$ & \\
\hline & TT & $18(0.222)$ & & $23(0.242)$ & \\
\hline \multirow[t]{3}{*}{ MC4R/rs7782313 } & $\mathrm{CC}$ & $6(0.063)$ & \multirow[t]{3}{*}{0.759355} & $5(0.053)$ & \multirow[t]{3}{*}{0.375208} \\
\hline & $\mathrm{CT}$ & $38(0.4)$ & & $27(0.287)$ & \\
\hline & TT & $51(0.537)$ & & $62(0.66)$ & \\
\hline \multirow[t]{3}{*}{ MC4R/rs12970134 } & AA & $5(0.057)$ & \multirow[t]{3}{*}{0.782620} & $3(0.031)$ & \multirow[t]{3}{*}{0.611424} \\
\hline & $\mathrm{AG}$ & $30(0.341)$ & & $24(0.25)$ & \\
\hline & GG & $53(0.602)$ & & $69(0.719)$ & \\
\hline \multirow{3}{*}{ SLC30A8/rs13266634 } & $\mathrm{CC}$ & $62(0.697)$ & \multirow[t]{3}{*}{0.038995} & $69(0.719)$ & \multirow[t]{3}{*}{0.08711} \\
\hline & CT & $21(0.236)$ & & $26(0.271)$ & \\
\hline & TT & $6(0.067)$ & & $1(0.01)$ & \\
\hline \multirow[t]{3}{*}{ KCNQ1/rs2237892 } & $\mathrm{CC}$ & $71(0.91)$ & \multirow[t]{3}{*}{0.04698} & $89(0.927)$ & \multirow[t]{3}{*}{0.03784} \\
\hline & $\mathrm{CT}$ & $7(0.09)$ & & $7(0.073)$ & \\
\hline & TT & 0 & & 0 & \\
\hline
\end{tabular}

Table 3. Genotype analysis of SNP polymorphism in diabetes cases and controls.

\begin{tabular}{|c|c|c|c|c|c|c|c|}
\hline SNP & Genotype & Cases & Controls & OR & $\mathrm{CI}$ & $\chi^{2}$ value & $\mathrm{P}$ value \\
\hline FTO & $\mathrm{AA}$ & $22(0.27)$ & $31(0.33)$ & Ref & & & \\
\hline \multirow[t]{3}{*}{ rs9939609 } & AT & $41(0.51)$ & $41(0.43)$ & 1.409 & $0.702-2.829$ & 0.93 & 0.33423 \\
\hline & $\mathrm{TT}$ & $18(0.22)$ & $23(0.24)$ & 1.103 & $0.484-2.514$ & 0.05 & 0.81599 \\
\hline & $\mathrm{AT}+\mathrm{TT}$ & $59(0.73)$ & $64(0.73)$ & 1.299 & $0.678-2.491$ & 0.62 & 0.43036 \\
\hline MC4R & $\mathrm{CC}$ & $6(0.06)$ & $5(0.05)$ & Ref & & & \\
\hline \multirow[t]{3}{*}{ rs17782313 } & $\mathrm{CT}$ & $38(0.40)$ & $27(0.29)$ & 1.173 & $0.324-4.241$ & 0.06 & 0.80779 \\
\hline & TT & $51(0.54)$ & $62(0.66)$ & 0.685 & $0.198-2.377$ & 0.36 & 0.54985 \\
\hline & $\mathrm{CT}+\mathrm{TT}$ & $89(0.94)$ & $89(0.95)$ & 0.833 & $0.245-2.830$ & 0.09 & 0.76982 \\
\hline MC4R & $\mathrm{AA}$ & $5(0.06)$ & $3(0.03)$ & Ref & & & \\
\hline \multirow{3}{*}{ rs12970134 } & $\mathrm{AG}$ & $30(0.34)$ & $24(0.25)$ & 0.614 & $0.322-1.171$ & 2.20 & 0.13766 \\
\hline & GG & $53(0.60)$ & $69(0.72)$ & 0.461 & $0.105-2.015$ & 1.10 & 0.29351 \\
\hline & $\mathrm{AG}+\mathrm{GG}$ & $83(0.94)$ & $93(0.97)$ & 0.535 & $0.124-2.31$ & 0.72 & 0.39558 \\
\hline SLC30A8 & $\mathrm{CC}$ & $62(0.77)$ & $69(0.72)$ & Ref & & & \\
\hline \multirow[t]{3}{*}{ rs13266634 } & $\mathrm{CT}$ & $21(0.26)$ & $26(0.27)$ & 7.429 & $0.828-66.62$ & 4.10 & 0.04280 \\
\hline & $\mathrm{TT}$ & $6(0.07)$ & $1(0.01)$ & 6.677 & $0.782-57.016$ & 3.92 & 0.04779 \\
\hline & $\mathrm{CT}+\mathrm{TT}$ & $27(0.33)$ & $27(0.28)$ & 6.867 & $0.810-58.217$ & 4.12 & 0.04234 \\
\hline KCNQ1 & $\mathrm{CC}$ & $71(0.91)$ & $89(0.93)$ & Ref & & & \\
\hline \multirow[t]{3}{*}{ rs 2237892} & $\mathrm{CT}$ & $7(0.09)$ & $7(0.07)$ & 2.194 & $0.618-7.791$ & 1.54 & 0.21473 \\
\hline & $\mathrm{TT}$ & $0(0)$ & $0(0)$ & - & - & - & - \\
\hline & $\mathrm{CT}+\mathrm{TT}$ & $7(0.09)$ & $4(0.07)$ & 2.194 & $0.618-7.791$ & 1.54 & 0.21473 \\
\hline
\end{tabular}

In the present study, we found no association between FTO [rs9939609 (A/T)], MC4R [rs17782313 (C/T) and rs12970134 (A/G)], and KCNQ1 [rs2237892(C/T)] gene variants and T2DM cases and matched healthy controls. Our data support that the SLC30A8 polymorphisms may be associated with T2DM in Saudi population.

\section{Genotype and allele frequencies of FTO, MC4R, SLC30A8, and KCNQ1 variants in Saudi and other populations}

We compared the genotypic and allelic frequencies of FTO, MC4R, SLC30A8, and 
KCNQ1 SNPs in a normal healthy Saudi population with those in HapMap project study groups. The allelic frequencies for most the SNPs were significantly different in the Saudi population compared with other populations represented in the HapMap project (Tables 4-8).

Table 4. Allele and genotype frequencies of FTO (rs9939609) in Saudi and other populations.

\begin{tabular}{|c|c|c|c|c|c|c|c|}
\hline \multirow[t]{2}{*}{ Population } & \multicolumn{3}{|c|}{ Genotype frequency (No.) } & \multicolumn{2}{|c|}{ Allele frequency } & \multirow[t]{2}{*}{$\chi^{2}$ test } & \multirow[t]{2}{*}{$P$ value } \\
\hline & AA & AT & TT & A & $\mathrm{T}$ & & \\
\hline $\operatorname{CEU}(\mathrm{N}=226)$ & $0.177(40)$ & $0.566(128)$ & $0.257(58)$ & 0.449 & 0.551 & 2.33 & 0.12 \\
\hline $\operatorname{HCB}(\mathrm{N}=86)$ & $0(0)$ & $0.233(20)$ & $0.767(66)$ & 0.116 & 0.884 & 36.53 & 0.001 \\
\hline JPT $(\mathrm{N}=172)$ & $0.035(6)$ & $0.302(52)$ & $0.663(114)$ & 0.186 & 0.814 & 36.09 & 0.001 \\
\hline YRI $(\mathrm{N}=222)$ & $0.243(54)$ & $0.532(118)$ & $0.225(50)$ & 0.509 & 0.491 & 0.233 & 0.625 \\
\hline $\mathrm{GIH}(\mathrm{N}=176)$ & $0.091(16)$ & $0.352(62)$ & $0.557(98)$ & 0.267 & 0.733 & 22.29 & SIG \\
\hline $\operatorname{MKK}(\mathrm{N}=284)$ & $0.268(76)$ & $0.521(148)$ & $0.211(60)$ & 0.528 & 0.472 & 0.058 & 0.81 \\
\hline SAUDI $(\mathrm{N}=95)$ & $0.326(31)$ & $0.432(41)$ & $0.242(23)$ & 0.542 & 0.458 & & \\
\hline
\end{tabular}

Table 5. Allele and genotype frequencies of MC4R (rs17782313) in Saudi and other populations.

\begin{tabular}{|c|c|c|c|c|c|c|c|}
\hline \multirow[t]{2}{*}{ Population } & \multicolumn{3}{|c|}{ Genotype frequency (No.) } & \multicolumn{2}{|c|}{ Allele frequency } & \multirow[t]{2}{*}{$\chi^{2}$ test } & \multirow[t]{2}{*}{$P$ value } \\
\hline & $\mathrm{CC}$ & $\mathrm{CT}$ & $\mathrm{TT}$ & $\mathrm{C}$ & $\mathrm{T}$ & & \\
\hline $\operatorname{CEU}(\mathrm{N}=226)$ & $0.035(8)$ & $0.460(104)$ & $0.504(114)$ & 0.265 & 0.735 & 1.55 & 0.21 \\
\hline $\operatorname{HCB}(\mathrm{N}=86)$ & $0(0)$ & $0.279(24)$ & $0.721(62)$ & 0.140 & 0.860 & 1.16 & 0.28 \\
\hline $\mathrm{JPT}(\mathrm{N}=172)$ & $0.058(10)$ & $0.372(64)$ & $0.570(98)$ & 0.244 & 0.756 & 0.68 & 0.41 \\
\hline YRI $(\mathrm{N}=226)$ & $0.097(22)$ & $0.434(98)$ & $0.469(106)$ & 0.314 & 0.686 & 3.96 & 0.04 \\
\hline $\mathrm{GIH}(\mathrm{N}=176)$ & $0.091(16)$ & $0.420(74)$ & $0.489(86)$ & 0.301 & 0.699 & 3.47 & 0.062 \\
\hline $\operatorname{MKK}(\mathrm{N}=286)$ & $0.042(12)$ & $0.329(94)$ & $0.629(180)$ & 0.206 & 0.794 & 0.017 & 0.9 \\
\hline SAUDI $(\mathrm{N}=94)$ & $0.053(5)$ & $0.287(27)$ & $0.66(62)$ & 0.2 & 0.8 & & \\
\hline
\end{tabular}

Table 6. Allele and genotype frequencies of MC4R (rs12970134) in Saudi and other populations.

\begin{tabular}{|c|c|c|c|c|c|c|c|}
\hline \multirow[t]{2}{*}{ Population } & \multicolumn{3}{|c|}{ Genotype frequency (No.) } & \multicolumn{2}{|c|}{ Allele frequency } & \multirow[t]{2}{*}{$\chi^{2}$ test } & \multirow[t]{2}{*}{$P$ value } \\
\hline & AA & $\mathrm{AG}$ & GG & A & G & & \\
\hline $\mathrm{CEU}(\mathrm{N}=226)$ & $0.035(8)$ & $0.487(110)$ & $0.478(108)$ & 0.279 & 0.721 & 5.51 & 0.018 \\
\hline $\operatorname{HCB}(\mathrm{N}=86)$ & $0(0)$ & $0.279(24)$ & $0.721(62)$ & 0.140 & 0.860 & 0.1 & 0.75 \\
\hline JPT $(\mathrm{N}=172)$ & $0.035(6)$ & $0.302(52)$ & $0.663(114)$ & 0.186 & 0.814 & 0.378 & 0.538 \\
\hline YRI $(\mathrm{N}=226)$ & $0.044(10)$ & $0.248(56)$ & $0.708(160)$ & 0.168 & 0.832 & 0.06 & 0.8 \\
\hline GIH (N = 176) & $0.102(18)$ & $0.398(70)$ & $0.500(88)$ & 0.301 & 0.699 & 7.36 & 0.0006 \\
\hline $\operatorname{MKK}(\mathrm{N}=286)$ & $0.028(8)$ & $0.266(76)$ & $0.706(202)$ & 0.161 & 0.839 & 0.01 & 0.91 \\
\hline SAUDI $(\mathrm{N}=96)$ & $0.031(3)$ & $0.25(24)$ & $0.719(69)$ & 0.157 & 0.843 & & \\
\hline
\end{tabular}

Table 7. Allele and genotype frequencies of SLC30A8 (rs13266634) in Saudi and other populations.

\begin{tabular}{|c|c|c|c|c|c|c|c|}
\hline \multirow[t]{2}{*}{ Population } & \multicolumn{3}{|c|}{ Genotype frequency (No.) } & \multicolumn{2}{|c|}{ Allele frequency } & \multirow[t]{2}{*}{$\chi^{2}$ test } & \multirow[t]{2}{*}{$P$ value } \\
\hline & $\mathrm{CC}$ & $\mathrm{CT}$ & TT & $\mathrm{C}$ & $\mathrm{T}$ & & \\
\hline $\operatorname{CEU}(\mathrm{N}=226)$ & $0.566(128)$ & $0.389(88)$ & $0.044(10)$ & 0.761 & 0.239 & 3.5 & 0.06 \\
\hline $\operatorname{HCB}(\mathrm{N}=86)$ & $0.279(24)$ & $0.512(44)$ & $0.209(18)$ & 0.535 & 0.465 & 22 & 0 \\
\hline JPT $(\mathrm{N}=172)$ & $0.302(52)$ & $0.523(90)$ & $0.174(30)$ & 0.564 & 0.436 & 23 & 0 \\
\hline YRI $(\mathrm{N}=226)$ & $0.867(196)$ & $0.124(28)$ & $0.009(2)$ & 0.929 & 0.071 & 4.49 & 0.03 \\
\hline GIH $(\mathrm{N}=176)$ & $0.602(106)$ & $0.341(60)$ & $0.057(10)$ & 0.773 & 0.227 & 2.6 & 0.1 \\
\hline $\operatorname{MKK}(\mathrm{N}=286)$ & $0.660(189)$ & $0.300(86)$ & $0.040(11)$ & 0.810 & 0.190 & 0.9 & 0.34 \\
\hline SAUDI $(\mathrm{N}=96)$ & $0.72(69)$ & $0.26(26)$ & $0.01(1)$ & 0.854 & 0.146 & & \\
\hline
\end{tabular}


Table 8. Allele and genotype frequencies of KCNQ1 (rs2237892) in Saudi and other populations.

\begin{tabular}{|c|c|c|c|c|c|c|c|}
\hline \multirow[t]{2}{*}{ Population } & \multicolumn{3}{|c|}{ Genotype frequency (No.) } & \multicolumn{2}{|c|}{ Allele frequency } & \multirow[t]{2}{*}{$\chi^{2}$ test } & \multirow[t]{2}{*}{$P$ value } \\
\hline & $\mathrm{CC}$ & $\mathrm{CT}$ & TT & $\mathrm{C}$ & $\mathrm{T}$ & & \\
\hline $\mathrm{CEU}(\mathrm{N}=226)$ & $0.850(192)$ & $0.150(34)$ & $0(0)$ & 0.925 & 0.075 & 3.58 & 0.05 \\
\hline $\operatorname{HCB}(\mathrm{N}=86)$ & $0.372(32)$ & $0.512(44)$ & $0.116(10)$ & 0.628 & 0.372 & 37.07 & 0.001 \\
\hline $\mathrm{JPT}(\mathrm{N}=172)$ & $0.407(70)$ & $0.465(80)$ & $0.128(22)$ & 0.640 & 0.360 & 39.25 & 0.001 \\
\hline YRI (N = 226) & $0.805(182)$ & 0.195 (44) & $0(0)$ & 0.903 & 0.097 & 5.71 & 0.016 \\
\hline GIH $(\mathrm{N}=176)$ & $0.977(172)$ & $0.023(4)$ & $0(0)$ & 0.989 & 0.011 & 0.38 & 0.53 \\
\hline $\operatorname{MKK}(\mathrm{N}=286)$ & $0.748(214)$ & $0.245(70)$ & $0.007(2)$ & 0.871 & 0.129 & 9.23 & 0.0003 \\
\hline SAUDI $(\mathrm{N}=93)$ & $0.957(89)$ & $0.043(4)$ & $0(0)$ & 0.98 & 0.02 & & \\
\hline
\end{tabular}

\section{Allele and genotype frequencies of SNP rs9939609 (A > T) of FTO gene}

The observed A/A, A/T, and T/T genotype frequencies were $0.326,0.432$, and 0.242 , respectively (Table 4). The A (wild-type) and T (variant) allele frequencies were 0.542 and 0.458 , respectively. The variant $\mathrm{T}$ (variant) allele frequency varied from 0.472 among MKK to 0.884 among HCB. All HapMap populations including CEU, HCB, MKK, GIH, YRI, and JPT were selected for this study, except for HCB, JPT, and MKK, all other populations were not significantly different from the CRS population when the pair-wise Chi-square $\left(\chi^{2}\right)$ test was used for analysis (Table 4).

\section{Allele and genotype frequencies of SNP rs17782313 (C > T) of MC4R gene}

The observed $\mathrm{C} / \mathrm{C}, \mathrm{C} / \mathrm{T}$, and $\mathrm{T} / \mathrm{T}$ genotype frequencies were $0.53,0.287$, and 0.66 , respectively (Table 5), whereas the $\mathrm{C}$ (wild-type) and $\mathrm{T}$ (variant) allele frequencies were 0.2 and 0.8 , respectively. The variant allele frequency varied from 0.686 (YRI) to 0.860 (HCB). No populations showed significant differences with the CRS population based on the pair-wise Chi-square $\left(\chi^{2}\right)$ test (Table 5).

\section{Allele and genotype frequencies of SNP rs12970134 (A > G) of MC4R gene}

The observed $\mathrm{A} / \mathrm{A}, \mathrm{A} / \mathrm{G}$, and $\mathrm{G} / \mathrm{G}$ genotype frequencies were $0.031,0.25$, and 0.719 , respectively (Table 6). The A (wild-type) allele frequency was 0.157 , whereas the $\mathrm{G}$ (variant) allele frequency was 0.843 . The variant allele frequency varied from 0.699 in GIH to 0.860 in $\mathrm{HCB}$. The GIH and CEU populations differed significantly from the CRS population based on pair-wise Chi-square $\left(\chi^{2}\right)$ test (Table 6 ).

\section{Allele and genotype frequencies of SNP rs13266634 (C > T) of SLC30A8 gene}

The observed $\mathrm{C} / \mathrm{C}, \mathrm{C} / \mathrm{T}$, and $\mathrm{T} / \mathrm{T}$ genotype frequencies were $0.72,0.26$, and 0.01 , respectively (Table 7). The $\mathrm{C}$ (wild-type) and $\mathrm{T}$ (variant) allele frequencies were 0.854 and 0.146 , respectively. The variant allele frequency differed from 0.071 (YRI) to 0.465 (HCB). The HCB, JPT, and YRI populations differed significantly from the CRS population based on pair-wise Chi-square $\left(\chi^{2}\right)$ test (Table 7).

\section{Allele and genotype frequencies of SNP rs2237892 (C > T) of KCNQ1 gene}

The observed $\mathrm{C} / \mathrm{C}, \mathrm{C} / \mathrm{T}$, and $\mathrm{T} / \mathrm{T}$ genotype frequencies were $0.957,0.043$, and 0 , re- 
spectively (Table 8). The $\mathrm{C}$ (wild-type) and $\mathrm{T}$ (variant) allele frequencies were 0.98 and 0.02 , respectively. The variant allele frequency differed from $0.011(\mathrm{GIH})$ to $0.372(\mathrm{HCB})$. Except for GIH, all populations differed significantly from the CRS population based on pair-wise Chi-square $\left(\chi^{2}\right)$ test (Table 8$)$.

\section{DISCUSSION}

T2DM is a common metabolic disease with an increasing prevalence, particularly over the past 2 decades (Wild et al., 2004). The rise in the incidence of this metabolic disease can be attributed to changes in lifestyle and diet and genetic components that interact with the environment. The incidence of diabetes among the people of Saudi Arabia has increased considerably, likely because of recent changes in lifestyle or diet (Elhadd et al., 2007). However, it is also possible that certain genetic predispositions contribute to these epidemic levels of T2DM. Various susceptibility genes for type 2 diabetes have recently been identified for several populations through genome-wide association studies (Ridderstråle and Groop, 2009). Genetic variants in FTO, MC4R, SLC30A8, and KCNQ1 were first reported by several studies performed in European and Asian populations (Saxena et al., 2007; Scott et al., 2007; Sladek et al., 2007; Zeggini et al., 2007; Loos et al., 2008; Yasuda et al., 2008). These polymorphisms have been confirmed in multiple studies examining various populations (Horikoshi et al., 2007; Steinthorsdottir et al., 2007; Omori et al., 2008).

In this case-control study, we observed an association between polymorphisms in the FTO, MC4R, SLC30A8, and KCNQ1 genes and T2DM in Saudi subjects. According to our results, the overall risk allele frequencies for these SNPs were significantly different between Saudi and other ethnic groups.

For rs9939609, our study showed that the Saudis have the highest frequency of ancestral allele (A) among the national groups listed in (Table 4). For rs17782313 MC4R, the frequency of minor allele (C) in Saudis is most similar to that in Japanese subjects (Table 5). Similar trends in allele frequencies were evident with rs12970134; the frequency of the ancestral allele $(\mathrm{G})$ in Saudis was the most similar to those in Yoruba (African) followed by Japanese, and furthest away from Europeans (Table 6). It is of interest to compare the allele frequencies of rs13266634 of SLC30A8 among several ethnic groups (Table 7). Our results show that the frequency of ancestral allele C in Saudis (0.85) was between Europeans $(0.76)$ and Yoruba (0.92), but the furthest from the Japanese (0.56). This is in direct contrast with results obtained for SNPs of MC4R mentioned above, where the allele frequencies in Saudis were the most similar to those of the Japanese. These results support the hypothesis that Saudis constitute a distinct population. Based on the allele frequency of KCNQ1 (rs2237892), our results suggested that the Saudis have the highest frequency of ancestral allele (C) (0.98) among all of the national groups listed in (Table 8). Similarly to the FTO SNP mentioned above, the allele frequencies of rs2237892 of KCNQ1 for Saudis, Yoruba, and Europeans are comparable, whereas the Japanese showed a distinct frequency.

In our study, rs13266634 of the SLC30A8 gene showed a significant association with T2DM. Alterations in the coding region of the SLC30A8 gene (ZnT-8) caused an amino acid change (Arg325Trp) in the intracellular C-terminus of the ZnT-8 protein. The SLC30A8 gene encodes a zinc transporter protein (ZnT-8) that is expressed in pancreatic alpha- and beta-cells (Chimienti et al., 2004). It localizes to the membrane of the insulin secretory granules, facilitates the accumulation of zinc from the cytoplasm in intracellular insulin-containing vesicles, 
and plays a major role in providing zinc for insulin maturation and/or storage processes (Chimienti et al., 2006). It was recently shown that SNP rs13266634, located in exon 8 (risk allele C), was associated with T2DM and reduced insulin secretion (Jansen et al., 2009). Although results of these studies remain controversial, there appears to be an association between the risk variant of rs 13266634 and reduced insulin secretion (Jansen et al., 2009). This conclusion requires further validations in larger groups.

There were no significant associations between FTO (rs9939609), MC4R [rs17782313 $(\mathrm{C} / \mathrm{T})$ and $\mathrm{rs} 12970134(\mathrm{~A} / \mathrm{G})]$, and KCNQ1 [rs2237892(C/T)] polymorphisms with either T2DM. It is possible that the number of subjects used in this study was small, and that further validation of our results is required using larger groups.

In conclusion, our results suggest that the Saudis are distinct group of people based on the allele frequencies for all 5 variants (Tables 4-8). This marker, which is tightly correlated with a disease variant in 1 population, may be only moderate or weakly associated with other groups. In this regard, the results showed possible association between diabetes with morphologies of the one SNP among five SNPs examined in this study. The results are promising, but required further validation using a larger number of subjects.

\section{ACKNOWLEDGMENTS}

The authors extend their appreciation to the Deanship of Scientific Research at King Saud University for funding the study through the research group preject \#RGP-VPP-081.

\section{REFERENCES}

Chambers JC, Elliott P, Zabaneh D, Zhang W, et al. (2008). Common genetic variation near MC4R is associated with waist circumference and insulin resistance. Nat. Genet. 40: 716-718.

Chimienti F, Devergnas S, Favier A and Seve M (2004). Identification and cloning of a beta-cell-specific zinc transporter, ZnT-8, localized into insulin secretory granules. Diabetes 53: 2330-2337.

Chimienti F, Devergnas S, Pattou F, Schuit F, et al. (2006). In vivo expression and functional characterization of the zinc transporter ZnT8 in glucose-induced insulin secretion. J. Cell Sci. 119: 4199-4206.

Dina C, Meyre D, Gallina S, Durand E, et al. (2007). Variation in FTO contributes to childhood obesity and severe adult obesity. Nat. Genet. 39: 724-726.

Elhadd TA, Al-Amoudi AA and Alzahrani AS (2007). Epidemiology, clinical and complications profile of diabetes in Saudi Arabia: a review. Ann. Saudi Med. 27: 241-250.

Frayling TM, Timpson NJ, Weedon MN, Zeggini E, et al. (2007). A common variant in the FTO gene is associated with body mass index and predisposes to childhood and adult obesity. Science 316: 889-894.

Hinney A, Vogel CI and Hebebrand J (2010). From monogenic to polygenic obesity: recent advances. Eur. Child Adolesc. Psychiatry 19: 297-310.

Horikoshi M, Hara K, Ito C, Shojima N, et al. (2007). Variations in the HHEX gene are associated with increased risk of type 2 diabetes in the Japanese population. Diabetologia 50: 2461-2466.

Jansen J, Karges W and Rink L (2009). Zinc and diabetes - clinical links and molecular mechanisms. J. Nutr. Biochem. 20: 399-417.

Lee YS (2009). The role of genes in the current obesity epidemic. Ann. Acad. Med. Singapore 38: 45-3.

Livak KJ (1999). Allelic discrimination using fluorogenic probes and the 5' nuclease assay. Genet. Anal. 14: 143-149.

Loos RJ, Lindgren CM, Li S, Wheeler E, et al. (2008). Common variants near MC4R are associated with fat mass, weight and risk of obesity. Nat. Genet. 40: 768-775.

McCarthy MI (2010). Genomics, type 2 diabetes, and obesity. N Engl. J. Med. 363: 2339-2350.

Omori S, Tanaka Y, Takahashi A, Hirose H, et al. (2008). Association of CDKAL1, IGF2BP2, CDKN2A/B, HHEX, SLC30A8, and KCNJ11 with susceptibility to type 2 diabetes in a Japanese population. Diabetes 57: 791-795.

Ridderstråle M and Groop L (2009). Genetic dissection of type 2 diabetes. Mol. Cell Endocrinol. 297: 10-17. 
Sambrook J, Fritsch EF and Maniatis T (1989). Molecular Cloning: A Laboratory Manual. 2nd edn. Cold Spring Harbor Laboratory Press, New York.

Saxena R, Voight BF, Lyssenko V, Burtt NP, et al. (2007). Genome-wide association analysis identifies loci for type 2 diabetes and triglyceride levels. Science 316: 1331-1336.

Scott LJ, Mohlke KL, Bonnycastle LL, Willer CJ, et al. (2007). A genome-wide association study of type 2 diabetes in Finns detects multiple susceptibility variants. Science 316: 1341-1345.

Sladek R, Rocheleau G, Rung J, Dina C, et al. (2007). A genome-wide association study identifies novel risk loci for type 2 diabetes. Nature 445: 881-885.

Staiger H, Machicao F, Fritsche A and Haring HU (2009). Pathomechanisms of type 2 diabetes genes. Endocr. Rev. 30: 557-585.

Steinthorsdottir V, Thorleifsson G, Reynisdottir I, Benediktsson R, et al. (2007). A variant in CDKAL1 influences insulin response and risk of type 2 diabetes. Nat. Genet. 39: 770-775.

Taylor AE, Sandeep MN, Janipalli CS, Giambartolomei C, et al. (2011). Associations of FTO and MC4R variants with obesity traits in Indians and the role of rural/urban environment as a possible effect modifier. J. Obes. 2011: 307542.

Unoki H, Takahashi A, Kawaguchi T, Hara K, et al. (2008). SNPs in KCNQ1 are associated with susceptibility to type 2 diabetes in East Asian and European populations. Nat. Genet. 40: 1098-1102.

van Tilburg J, van Haeften TW, Pearson P and Wijmenga C (2001). Defining the genetic contribution of type 2 diabetes mellitus. J. Med. Genet. 38: 569-578.

Wild S, Roglic G, Green A, Sicree R, et al. (2004). Global prevalence of diabetes: estimates for the year 2000 and projections for 2030. Diabetes Care 27: 1047-1053.

Yasuda K, Miyake K, Horikawa Y, Hara K, et al. (2008). Variants in KCNQ1 are associated with susceptibility to type 2 diabetes mellitus. Nat. Genet. 40: 1092-1097.

Zeggini E, Weedon MN, Lindgren CM, Frayling TM, et al. (2007). Replication of genome-wide association signals in UK samples reveals risk loci for type 2 diabetes. Science 316: 1336-1341. 